Revista Iberoamericana, Vol. LXXVIII, Núm. 241, Octubre-Diciembre 2012, 873-892

\title{
ESTÉTICA DEL DERRUMBE: ESCRITURA Y DEAMBULAR URBANO EN LA OBRA DE EDUARDO LALO
}

\author{
POR \\ Francisco JaVIER AvilÉs \\ University of Pittsburgh \\ Y si al llegar, Borikén es la misma \\ que te obligó al exilio, sacrifícala \\ Manuel Ramos Otero, "Kavafis” \\ L'Inconscience est un patrie; la conscience, un exil. \\ E. M. Cioran ${ }^{1}$
}

Walter Benjamin en "Berlin Chronicle”, un texto de singular potencia, en el que se entrelazan el ángulo narrativo, la pasión crítica y la evocación íntima, construye minuciosamente la imagen del escritor como la de un arqueólogo. Benjamin narra cómo su formación intelectual estuvo desde siempre ligada a la educación de los sentidos y que a su vez ambas formaciones estuvieron indisolublemente ligadas a los recorridos por la ciudad. Ocultos en los rincones de Berlín había restos y signos a la espera de la sensibilidad del escritor, signos que ya eran la materia originaria de la escritura. La experiencia urbana es entonces una arqueología del sentido que se cifra como "conciencia topográfica” (Demetz xvii) donde la errancia lúcida se transforma en estrategia de abordaje al texto.

En este trabajo abordaré la obra del escritor puertorriqueño Eduardo Lalo como si fuera una máquina cínica ${ }^{2}$ que es a la vez un diagnóstico y un síntoma de escribir en Puerto Rico, un “país invisible”. Me concentraré en dos de sus últimos textos donde

1 Todas las citas de Cioran están tomadas de De l'incovénient d'être né. Paris: Gallimard, 1973.

2 Más adelante veré las tensiones que el cinismo opera en el texto, pero sirva en esta instancia introductoria aclarar que hay que desechar las nociones convencionales que se tienen sobre el cínico para no limitar el ejercicio de lectura en Lalo. El cinismo suele definirse de manera negativa, una especie de bufón que piensa que todas las acciones humanas están motivadas por el egoísmo. Pero también se sabe que el cinismo es una actitud filosófica nacida en la antigüedad griega que rechazaba la excesiva dogmatización y fomentaba la disciplina y la "vida mínima”. Es esta última noción la que hay que conservar para leer a Lalo. 
y Los países invisibles, pero no se puede llevar a cabo un ejercicio crítico a la obra de Lalo sin tener en cuenta que ésta es un aparato orgánico que se refiere a sí misma constantemente, como lo hace la obra de todo gran escritor.

La hipótesis de este ensayo es que en la obra de Lalo se encuentran el paradigma cínico -la "vida de perro"- con el flâneur estudiado por Benjamin en la obra de Baudelaire. No consideraré a Baudelaire en mi argumento, sino el dispositivo teórico que fabrica Benjamin con él: el ocioso caminante urbano. En la textura de la escritura de Lalo converge la voluntad del filósofo marginal con la itinerancia del poeta que busca en la ciudad la inmanencia de su sensibilidad.

\title{
I. ARQUeOLOGÍA DEL LUGAR
}

\begin{abstract}
En arriver à n'avoir plus à quoi renoncer! Tel devrait être le rêve de tout esprit détrompé.
\end{abstract}

\section{E. M. Cioran}

La obra de todo escritor pasa por procesos de sintonización, esa búsqueda de la voz donde se persigue el código simbólico que sirva para aludir al mundo. La escritura consecuente va dejando objetos, trazos, que se depositan en la cultura para que el lector vaya a desenterrarlos.

He who seeks to approach his own buried past must conduct himself like a man digging [...] for the matter itself is only a deposit, a stratum, which yields only to the most meticulous examination what constitutes the real treasures hidden within the earth: the images, severed from earlier associations, that stand in the prosaic rooms of later understanding. (Benjamin, Reflections 26)

Lo mismo puede decirse del trabajo crítico que aquí se emprende. Los primeros textos de Eduardo Lalo, que pasaron casi totalmente desapercibidos al ser publicados por primera vez, luego se reunieron en La isla silente (2002) que recoge: Ciudades e islas (1995), Libro de textos (1992) y En el Burger King de la Calle San Francisco (1986). Lo primero que salta a la vista en esta literatura es su condición de minoridad, es una literatura adherida incómodamente a una tradición (o tradiciones) vasta y compleja (la puertorriqueña), una literatura (la de Lalo) que se esfuerza por pensarse a sí misma como otra. Lalo se aleja de cierto territorio lingüístico puertorriqueño, cierta manera de "hacer" la letra en Puerto Rico. El texto de Lalo sospecha que la literatura en Puerto Rico tenga que en algún momento aludir al humor; que el escritor tenga que construir oraciones alambicadas, seudo barrocas, para atrapar el "sabor” del Caribe; que la seriedad estética la otorgue la vibración en el texto de la jerga; que haya que aludir a cierto difuso orgullo de “pertenecer” venga éste en forma política o en forma literaria.

Revista Iberoamericana, Vol. LXXVIII, Núm. 241, Octubre-Diciembre 2012, 873-892
ISSN 0034-9631 (Impreso) 
La incomodidad con el lugar es también la honestidad de la mirada; la literatura debe hacerse caminando, tropezando con la escritura en la ciudad, no con el fantasma de una tradición que no se reconoce. Eduardo Lalo se expresa así en una entrevista realizada por Ana María Amar Sánchez:

\begin{abstract}
La particularidad puertorriqueña en este proceso [el de "crear un universo literario"] es que vivimos el desarrollo de nuestra literatura con unos fotogramas de desface. De ahí que, por ejemplo, la narrativa de la llamada generación del 70 (con sus excepciones, por supuesto, en especial Manuel Ramos Otero) parezca la versión cuentística de lo que los autores del boom vertieron en novelas. Así el barroco, lo real-maravilloso, la literatura fantástica, etc. se manifestaron en Puerto Rico con el sabor rancio de una tienda de ultramarinos. Por ello, para mí, esos textos no cuajaban ni entusiasmaban del todo, pues no los veía surgir de las calles que pisaba. No poseían muchas veces ni siquiera la frescura de la parodia; eran el homenaje ingenuo a las vacas sagradas que no se interesarían nunca por leer a estos autores. (Amar Sánchez 38)
\end{abstract}

Lalo lanza sus martillazos contra lo que entiende es una forma de cárcel, contra la fatalidad del lugar, pero en esa fatalidad se cifra la fuerza y la inevitabilidad de la literatura. El escritor reconoce que lo es cuando se enfrenta a su espacio como una forma de tragedia, desnudar al texto de las categorías del deber y de lo correcto para que el lugar aparezca en la escritura en su terrible desnudez. "La escritura de Lalo es un trance que apuesta al fracaso del lugar, a su inutilidad” (Duchesne 7). La inutilidad, la absoluta contingencia del lugar, es la carne con la que está hecha el cuerpo del texto.

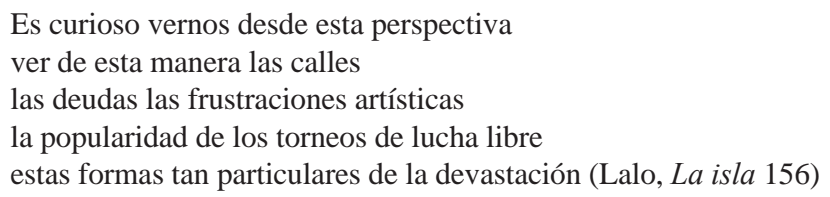

La minoridad se cifra en una especie de insignificancia gozosa, el artista, el escritor, llega a la convicción de que la literatura brota de la grieta. El narrador-ensayista de En el Burger King de la calle San Francisco ve monstruos por todas partes (el corto texto tiene incluso una sección llamada “Catálogo de monstruos”), animales agazapados en las esquinas, criaturas que quieren colarse al texto, formas mutadas de la humanidad. El “yo” que se forja en la escritura le enseña al mundo sus cuadernos de apuntes (Lalo todavía escribe a mano sus libros son literalmente, antes que nada, manuscritos) y lo que se ve es un espejo. Así va apareciendo el lugar en la espesura que se forma entre la vida y la página, el escritor recoge los trozos en su cuaderno para que adquiera coherencia el espacio que se habita:

\footnotetext{
Revista Iberoamericana, Vol. LXXVIII, Núm. 241, Octubre-Diciembre 2012, 873-892 ISSN 0034-9631 (Impreso) 
Los monstruos duermen en las calles. Redescubren el sentido primero del horizonte: la no-propiedad. Cualquier saliente de umbral y cualquier escalón puede [sic] ser su casa. Subestiman los planos verticales -las paredes- pues en lo que sube no se encuentra reposo y los muros les recuerdan su fracasada condición de bípedos. (Lalo, La isla 203)

El ensayista también se inventa un exilio en esa "no-propiedad”, que devendrá el “donde” que veré más adelante, una marginalidad radical a la intemperie, alejado del techo de la casa de la literatura puertorriqueña. Ve la tragedia pero también ve su propio rostro. Los monstruos y el escritor se entrelazan misteriosamente, como los animales en Kafka (el perro, las ratas), las criaturas que habitan La isla silente son figuras de la derrota que algo nos dicen sobre la importancia de sospechar de lo humano. La colección de bestias urbanas que es La isla silente "es un mapa de intensidades" (Deleuze 56) que buscan una salida, un plan de evasión que reitere el ethos del escritor. El primer texto de Lalo ya anuncia una cartografía del desastre, el impulso por encontrar lo literario precisamente allí donde vibra el final. "Una literatura menor no es la literatura de un idioma menor, sino la literatura que una minoría hace dentro de una lengua mayor" (Deleuze y Guattari 28). Lalo se adentra en el territorio de la literatura puertorriqueña (esa lengua mayor) para producir un discurso menor, una forma de alusión que lleva la desterritorialización hasta el punto que sólo quedan las intensidades del escritor (Deleuze y Guattari 33). Los primeros envíos que se recogen en La isla silente marcan los puntos de fuga o las salidas del territorio. Ciudades e islas está compuesta de un relato largo "In memoriam" y siete relatos cortos: ocho formulaciones del exilio, ocho formas de salir que son también estrategias de regreso, de reterritorialización. El universo narrativo, poético y ensayístico de Lalo está habitado por un "yo" que asiste constantemente a su despoblamiento, al vaciado de su subjetividad que paradójicamente marca la singularidad del enunciante. Así dice en "In memoriam":

El relato al que he llegado concluye, que antes de los acontecimientos que motivarían mi partida, ésta ya estaba de alguna forma decidida. Y esta cualidad pudo ser independiente de la voluntad y los actos... Las extremidades, el torso, la respiración, los sueños, sufrían de un aumento de presión y luchaban por librarse de algo que parecía a la vez un molde y una celda. (La isla 66)

El relato describe la vida de Privat y es un testamento escrito para un exiliado o, usando la palabra que prefiere el narrador: un póstumo. ${ }^{3}$ Un póstumo que se negó a

3 Este término evoca, por supuesto, uno de los personajes más importantes de la literatura puertorriqueña, el protagonista de la novela Póstumo, el transmigrado de Alejandro Tapia y Rivera. Sin embargo, no encuentro correspondencias entre ambos personajes ni entre ambos textos, salvo, quizás, de una manera alegórica. El póstumo de Tapia muere y resucita primero en el cuerpo de un hombre y luego en el de

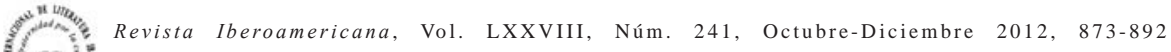
ISSN 0034-9631 (Impreso) ISSN 2154-4794 (Electrónico)
} 
negociar con una literatura intermedia, chata, que no involucra radicalmente al lector en la vida del texto. Escrito "para" porque lo escribe un testigo que deambuló con este póstumo por la ciudad. Walter Benjamin, en uno de los múltiples ensayos que escribió sobre Charles Baudelaire, argumenta que el destino final del flâneur es la muerte. Aquí cita el emblemático último poema de Les fleurs du mal: "O Mort, vieux capitaine, il est temps! levons l'ancre / [...] Au fond de l'Inconnu pour trouver du nouveau!” La muerte, la ciudad y lo nuevo se intercambian valores en las categorías críticas de Benjamin. La ciudad produce lo nuevo en forma de fetiche como mercancía muerta, vaciada de su valor originario, aurático (Benjamin, The Writer 41). Para Benjamin, Baudelaire abre la posibilidad de una lectura crítica de la modernidad desde la práctica visceral de la deambulancia. El poeta entrega su cuerpo a las calles de la ciudad, se deja atravesar por ellas para hacer aparecer un texto desde esas entrañas. Las ciudades expresan el paradigma de la saturación capitalista, que para Benjamin es una especie de tormenta (también llamada progreso) que solo deja en la historia una inmensa montaña de escombros.

Where we perceive chain of events, he sees [se refiere al ángel de la historia] one single catastrophe which keeps pilling wreckage upon wreckage and hurls it in front of his feet. The angel would like to stay, awaken the death, and make whole what has been smashed. But a storm is blowing from Paradise; it has got caught in his wings with such violence that the angel can no longer close them. This storm irresistibly propels him into the future to which his back is turned, while the pile of debris before him grows skyward. This storm is what we call progress. (Benjamin, Illuminations 256)

La clave para leer la modernidad que Benjamin nos invita a encontrar aquí, el ángel que mira impávido la destrucción, es que hay que sospechar de la deificación del progreso y de la ciencia cuando éstos producen una forma de subjetividad que hace del olvido una forma de supervivencia ontológica. ${ }^{4}$ Por eso el escritor personificado en el flâneur -y en el mismo trabajo crítico que Benjamin llevó a cabo en el Das PassagenWerk- es un arqueólogo rescatando esos efímeros fogonazos del presente: la vitrina, la mujer que pasa, el objeto olvidado, el niño con el helado. El poeta se adentra en la acumulación de desperdicios que es la ciudad para extraer belleza. La muerte pierde su negatividad porque la escritura es la honestidad que le queda al caminante. El poetaescritor-arqueólogo sigue siendo uno de los pocos con la opción de no traicionarse, de dejar una marca en la pared, un grafiti que lo diga, aún con la convicción de que sus libros van algún día a engordar la pila de basura. Con este registro se debe leer los libros posteriores de Lalo (Los pies de San Juan, donde y Los países invisibles), o las fotos

una mujer. El sentimiento de descolocamiento que expresa Póstumo podría compararse con la noción de marginalidad según elaborada por Lalo.

4 “En lo nuevo, ¿dónde trazar la frontera entre realidad y apariencia?” ver Benjamin citado por BuckMorss (111).

\footnotetext{
(1) Revista Iberoamericana, Vol. LXXVIII, Núm. 241, Octubre-Diciembre 2012, 873-892 ISSN 0034-9631 (Impreso) 
e imágenes que acompañan dos de éstos, marcas en el pellejo seco de la colonia, ese emporio donde la voluntad del Otro se muestra en toda su crueldad. "In memoriam": "Mi única justificación es estar vivo, haber sobrevivido para contarlo" (La isla 21).

Es significativo que el relato "In memoriam" comience describiendo el primer contacto del narrador en la Ciudad con la obra de Baudelaire. El poeta francés se figura como emblema del exiliado en su tierra y también como un habitante del Trópico. "Baudelaire, sin poder serlo por su origen, fue uno de los primeros escritores de las Islas" (23). En la obra de Lalo, Puerto Rico es antes que todo un espacio, un lugar donde es posible estar: la escritura es el ejercicio que se realiza para descifrar ese adverbio de lugar y ese verbo. Baudelaire representa "el daño hecho a los hombres y las mujeres de la franja central del planeta, en el vislumbre de la maladaptación perenne de esas poblaciones, se encuentra antecedida la palabra propia y repetida de generaciones de isleños” (23). La literatura entonces es un síntoma, la herida abierta por el estar, la detallada exposición del daño. La tradición de la entidad radicalmente sola vagando por la ciudad recogiendo los signos que flotan en el vaho del presente, es la tradición en la que se inscribe Lalo, o la criatura que se forja en sus textos. Es un lugar en el que se puede ser póstumo antes de morir, porque la muerte se codifica como alternativa ante el desasosiego, ese panorama baldío que se ofrece a la mirada. La desaparición sólo como figura de palabra sobretodo, como un dispositivo que hace aparecer el espacio de la crítica: soy un muerto para el Otro pero insisto en dejar mi huella aquí, por eso escribo, para que mi sombra se instale, se performe en la grieta. ${ }^{5}$ El lugar aparece en las franjas de la letra, se recoge en el camino pero se vuelve espacio cuando se figura en la práctica metódica del cuaderno. La formulación "isla silente" del título de la recopilación recoge la vocación arqueológica que se iba creando Lalo. El a-isla-miento no sólo recoge la condición de vivir en una isla sino la capacidad de hacerse isla, de tomar para sí la radicalidad de cierta soledad lúdica. ${ }^{6} \mathrm{El}$ aislado que apunta las cicatrices que el silencio ha abierto en las paredes de la ciudad, pero apuntar para también dejar el grafiti que conjure el olvido aunque a nadie le importe. "Escribir como un perro que escarba un hoyo, una rata que hace su madriguera. Para eso: encontrar su propio punto de subdesarrollo, su propia jerga, su propio tercer mundo, su propio desierto” (Deleuze 31).

"Era como si la Ciudad en un aspaviento de generosidad y paternalismo, hubiera inventado para algunos una carrera hasta entonces desconocida, el destino equívoco de una inmortalidad nueva. En la Ciudad existía la posibilidad de ser póstumo" (Lalo, La isla 59). No sólo en "In memoriam”, también en "George de Porto Riche”, "Compatriotas”

5 En La isla silente ya se puede intuir la sombra que puebla los textos posteriores. Esas sombras que se desplazan a lo largo de las fotos y las imágenes en Los pies de San Juan, donde y Los países invisibles ya estaban apareciendo en en La isla.

6 "Some islands drifted away from the continent, but the island is also that toward one drifts; other islands originated in the ocean, but the island is also the origin, radical and absolute”, Deleuze (10).

Revista Iberoamericana, Vol. LXXVIII, Núm. 241, Octubre-Diciembre 2012, 873-892
ISSN 0034-9631 (Impreso) 
y en todos los textos de Ciudades e Islas, las palabras póstumo, exiliado y escritor están usadas de manera análoga, intercambiable, para designar lo marginal. La ciudad hace póstumo a escritores de extrema sensibilidad literaria como Privat; lo póstumo no sólo es una manera de vivir la literatura y dejarse vivir por ella, sino también es una manera de ejercer la ciudad, de escribirla y dejarse escribir por ella. Lo póstumo se asume como manera de desaparición, una instancia en la conciencia del habitante de la ciudad en el que se reconoce que vivir las calles de la ciudad es aspirar a no ser visto: el anonimato es la metafísica de la ciudad. He aquí una forma radical de marginalidad que la relación escritura/ciudad le ha dado al póstumo: el margen es una radicalización de la vida. "La marginalidad no es una forma antihumana de ser. Es una de las formas universales de lo humano, y me atrevería a añadir, que es una de las formas más aptas para que la complejidad de la vida se manifieste, comprenda y exprese” (La isla 27). Ser póstumo anuncia una sensibilidad inútil, que no puede gastarse, invertirse en el espacio de circulación del capital. ${ }^{7}$

Ciudades e Islas es una arqueología de San Juan, un documento sobre las ruinas de la ciudad espiritual. San Juan es también un lugar en la imaginación y es desde ese lugar que el poeta-flâneur la construye. El texto es una transcripción de los signos vitales de la Ciudad: es el lugar donde la Ciudad se vuelve habitable (solo con la escritura), y hasta querida con todas sus miserias, precisamente porque mirarla tal cual otorga el placer de la lucidez, de lo inevitable. "In memoriam" es un relato resplandeciente que anuncia una literatura puertorriqueña madura y dispuesta a aceptar los retos de la escritura posnacional. Anuncia un sujeto literario dispuesto a mirarse en el espejo, ser honesto con la condición póstuma y seguir escribiendo.

CODA: TRANSICIÓN: PAUTAS PARA QUEDARSE

Un lieu que j'ai parcouru, je ne m'en souviens que si j'ai eu la veine d'y connaître quelque anéatissement par le cafard.

\section{E. M. Cioran}

La isla silente es un texto de itinerarios y desvíos, formas elementales del tránsito. Luego de Los pies de San Juan (2002) Lalo publica La inutilidad (2004), y ya está más sólida la noción de lugar, un espacio que es siempre atravesado por el tránsito, por el

\footnotetext{
7 Es útil, desde luego, mientras leemos a Lalo recordar la reflexión de Julio Ramos sobre la escritura menor de Luisa Capetillo: “Ante la pregunta matriz del ensayo puertorriqueño -qué somos- la escritura menor no hace sino marcar su silencio [...] Ante la pregunta de la identidad la escritura menor desliza la mirada aguda e iluminadora hacia las contradicciones, hacia las problemáticas locales que constituían zonas invisibles de la puertorriqueñidad” (Ramos 69).
}

ISSN 0034-9631 (Impreso) 
cuerpo del caminante que escribe. El texto podría pensarse como un "In memoriam" extendido, la voz narrativa revisita los lugares de póstumo y les da espesor narrativo.

La novela está dividida en dos secciones: París y San Juan. Transcripciones narrativas de estados espirituales, estas ciudades se convierten en emblemas urbanos de una elaborada reflexión sobre el fracaso y el poder de la literatura y el arte para entender y trascender la catástrofe. París guarda en sus calles una sombría tendencia a abrumar, a sobrepasar, a aplastar con su vastedad: "París era severo. Era una especie de orfanato de adultos. A pesar de la sofisticación, pocos parecían abordar directamente sus problemas. Siempre había una causa externa y una gran teoría para ocultar las verdaderas razones y responsabilidades” (24). Una ciudad que facilita la desaparición y que posibilita espacios para ejercer la distancia, que también era una ciudad para fortalecer la subjetividad mediante el descarnado efecto de la soledad. En el texto de Eduardo Lalo la inutilidad de la literatura puede ser leída como una voluntad ética.

Uno de los logros más significativos de este texto es que transmite una profunda carga emocional utilizando un estilo y un lenguaje sin pretensiones, sobrio y compacto, como un oleaje vago arrastrando crustáceos muertos. Es Onetti sin la sintaxis elaborada. Las escenas se entrelazan como sombras atascadas en grietas agobiadas por la luz. En una especie de lúgubre fluir de la trama se van sucediendo un sin número de gestos caducos que van clausurando personajes. Se clausura a Simone y a Marie; Petremont muere cuando ya el narrador está de regreso en San Juan; Alejandro, el poeta en el que se cifraron algunas esperanzas, se desvanece en los bordes del texto devorado por las estridencias del país; Esteves muere olvidado y corroído por el fracaso. Toda esta procesión de salidas se pasea por la mirada del lector que casi no logra darse cuenta que le están haciendo una parsimoniosa cartografía de la catástrofe. La inutilidad es el cuaderno de un etnógrafo que está asistiendo a la destrucción de una cultura.

En La escritura del desastre, Maurice Blanchot plantea que la tarea más legítima de la escritura es escribir sobre lo no-posible, sobre ese límite en el que veo mi muerte, mi destrucción. El escritor encuentra unos signos entre las ruinas y los convierte en lenguaje. De aquí la importancia de la etnografía en el texto de Lalo, es una separación y una aproximación. El narrador está llevando a cabo la inutilidad más importante, está adentrándose en el desastre de un San Juan en ruinas, de un París implacable con unas criaturas sobreviviendo en una ciudad que los supera, de unas subjetividades corroídas por la derrota, de una identidad sola, libre y agotada, y de ahí, precisamente de ahí, está construyendo la escritura, el gesto inútil por excelencia, pero también el gesto de apertura al otro.

El periplo del personaje principal por las ciudades de París, Alicante y San Juan lo deja convencido que la desolación es la estructura básica de la realidad, el mundo es un elaborado enjambre que sólo se esfuerza en olvidarte. Hay que construir con la derrota (no con el fracaso) las máquinas de supervivencia. La inutilidad termina anunciando

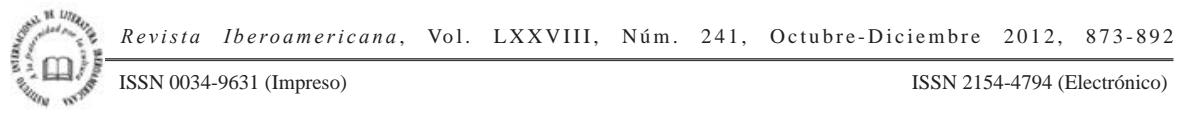


el nacimiento de una voz: "El mar es el desierto de la ciudad y la isla y el mar es para ahogarse. ${ }^{8}$ Puedo decir que casi soy feliz al darme cuenta. Por fin esta tierra es mía" (Lalo, La inutilidad 182). La inutilidad es un texto sobre la llegada, el escritor arqueólogo se ha convertido en un etnógrafo, ahora sabe que puede hacer la historia que extrajo de entre las ruinas, ahora sabe qué hacer cuando aparezcan más ruinas, está listo para el donde y la invisibilidad.

El GARABATO DEL PERRO REALENGO

Toutce qui est encoré vivant dans le floklore vient d'avant le christianisme. - Il en est de meme de tout ce qui est vivant en chacun de nous.

\section{E. M. Cioran}

Los textos de Lalo se empeñan en nombrar y en recorrer el lugar. En su itinerario como escritor por el panorama semi desértico de la literatura puertorriqueña, Eduardo Lalo se va deliberadamente a las antípodas de lo visible para mostrar con ese gesto la obscenidad exhibicionista del mercado literario. Aparece así en esta literatura un nuevo personaje: el quedado. Si en La inutilidad el exilio se codifica como cicatriz espiritual, como la única forma de estar, en donde la extranjería adquiere densidad ontológica y se convierte en la máquina de alusión que transforma estéticamente la relación entre el lugar y el cuerpo que escribe. Aludir, construir un lector, formar vasos comunicantes aunque sean imaginarios, ese empeño por quedarse en un espacio y por esculpirlo con la palabra es el registro discursivo del trabajo de Lalo en donde. Este texto es antes que todo una dialéctica separación/alusión. El narrador (que plantea que el texto es un ensayo y una novela, entre otras cosas) marca su irreconciliable diferencia (su "pathos de la distancia", Nietzsche) con los literatos de la visibilidad y el "figureo" que decoran la escena literaria de Puerto Rico, o, como la define el crítico Juan Carlos Quintero Herencia, "la lógica aduanal” de los escritores insertados en la maquinaria del mercado (22). Pero también es una invitación a caminar el "donde”, a adentrarse en la pasión del arte que emerge precisamente de allí donde las fuerzas se empeñan en hacerla desaparecer:

Hasta hoy en la literatura y en la historia, el exiliado ha sido un personaje protagónico. Propongo otro: el quedado, el regresado, el que no puede (o no quiere) ir a ninguna parte. (¿A qué parte en un mundo en que los exilios comienzan a ser imposibles?) Apuesto por la pertinencia de estos seres, por su heroísmo domiciliario. Escribo para defender nuestro derecho a la tragedia. (Lalo, donde 95)

8 “[El mar] era como una gran tumba azul y me daba la sensación de estancamiento”. Entrevista a Manuel Ramos Otero (Costa 66).

ISSN 0034-9631 (Impreso) 
El quedado podría pensarse como una nueva categoría conceptual en el universo de la literatura puertorriqueña. Como dispositivo político hay que pensarlo como un exceso que produce la patología colonial, el callejón sin salida del estatus lanza a los ciudadanos coloniales al ostracismo más abyecto. El quedado es quien sabe que irse es imposible, que el rincón que toca guarda una fracción de poder desde donde se puede interpelar a ese Otro lejano y, por qué no, cuestionar los límites de su poder con el instrumento precario de la palabra. "El lugar [en donde] no es una geografía sino una condición, es una manera de habitar, de estar y de vivir muy lúcida” (Negrón 306). El quedado también es un dispositivo de resistencia estética, un renunciante que aspira como diría Cioran o el monje budista ${ }^{9}$ a hacer irrelevante toda renuncia. El quedado es el que resiste los grupos, el que se queda fuera de los oropeles porque sabe que la escritura es como la filosofía de los cínicos, una práctica cotidiana como respirar.

El escritor se mueve entre los trozos del presente como un arqueólogo. La metáfora arqueológica no es gratuita, el escritor está dentro de la cultura, pero también fuera de ella. Depreda en el objeto encontrado para producir un texto interpretativo, una forma de alusión. Sin embargo, en el donde, aludir se vuelve un gesto vacío, una práctica precisamente inconsecuente porque el mecanismo del gesto (la escritura) cada vez importa menos. Si en El crepúsculo de los ídolos Nietzsche aseguraba estar filosofando a martillazos, en donde Lalo escribe a martillazos. La escritura brota de las ruinas, del desastre, como un grafiti indescifrable en una pared baldía que de alguna manera le da sentido a las ruinas: "Las palabras [nos sirven] para la comprobación constante, el examen perenne de la magnitud de nuestras equivocaciones” (donde 33). Se puede decir de Lalo lo mismo que dice Iván de la Nuez sobre Kundera o Zizek, son “ideólogos originales para el poscomunismo porque ofrecen islotes de la vida privada como pequeños escondites opuestos a los designios del totalitarismo, bien sea la dictadura anterior del Estado comunista, bien sea la actual dictadura del mercado capitalista” (De la Nuez 26). Donde dice “poscomunismo” dígase "nueva izquierda” y donde dice "Estado comunista” dígase "gobierno del Estado Libre Asociado".

La voluntad arqueológica se enlaza con una postura ética, una actitud hacia el otro que sospecha de su dejadez, que le increpa sobre su vagancia mental:

Más allá de una concepción gentilicia nacional de esta pantalla vacía del “donde”, la propuesta ética de Lalo se ata a la historicidad básica que firma la efectividad del género novela, la significación, la escritura del sentido en un mundo des-espiritualizado, donde son inoperantes las explicaciones nativistas, trascendentes. (Quintero Herencia 22)

\footnotetext{
9 Lalo es un practicante de la meditación Zen. Hace falta un trabajo sistemático sobre la influencia del pensamiento budista en Eduardo Lalo. ¿Cómo funciona la idea del vacío budista en la noción del quedado, esa especie de soledad dura?

ISSN 0034-9631 (Impreso)
} 
La escritura en Puerto Rico está enferma de identitis -tomando prestado el concepto de Juan Duchesne ("Fatiga")-, la saturación identitaria ha llegado a un punto paroxístico y no hay escapatoria, el colonialismo fuerza a la colonia a devorarse a sí misma. donde, en cambio, es una estrategia de evasión, una apuesta por una escritura otra que emana precisamente de este caldo de cultivo: “ ¿En lugar de una literatura de lo dado, del espacio incuestionado, puede crearse una literatura del donde, del espacio espeso?” (Lalo, donde 91). Si la gestión creativa está asediada por la desaparición, entonces asumir radicalmente la tachadura como práctica literaria. En una entrevista en la revista Katatay, Ana María Amar Sánchez le preguntó a Lalo sobre esta idea del espacio espeso y Lalo respondió así:

El espacio espeso es un arma contra la claustrofobia; es un decir, un añadir cuando se habían sentado las condiciones para el silencio. En este sentido constituye una forma de rebelión y una estrategia operativa del dolor. Éste se convierte, aunque sea brevemente, en el gozo del superviviente. Escribo quizá para consolar a otro. (Amar Sánchez 41)

El donde es también la piel en la que el quedado dibuja los signos de su estadía en el mundo, el pergamino, quizá un arqueólogo rescate el documento de los escombros en el porvenir. El espacio espeso es la celda mental del escritor con la que se resiste el acecho del paso de las horas y el tedio. Esto por supuesto evoca el shock bejaminiano. En "The Storyteller” Benjamin elabora la teoría de que la narrativa moderna surgió cuando los soldados que regresaban de la guerra no podían expresar el horror con el habla, las lágrimas y las emociones sino que tenían que expresar u ocultar creativamente lo que sentían en la palabra escrita. La proliferación de la prensa y las editoriales son un fenómeno de la posguerra. El shock es una máquina de percepciones que crea al sujeto moderno. El shock es positivo y negativo, oculta y deja ver a la misma vez, aleja al sujeto de cierta tradición oral pero lo acerca al signo, a la letra para expresar la experiencia de lo nuevo. Con estas claves se puede leer el "espacio espeso" del donde. La acumulación de escombros que es la historia occidental acorrala las afectividades y tacha a los sujetos. "Nacimos para ser rayados. Nuestros textos, este mismo que ahora escribo, se inscriben en una tradición que desde su primer día, los niega. Escribimos para decir que muerte y nacimiento son una misma cosa. Juan de Castilla, Điego Colón, Edturdo Lalo” (Lalo, donde 127). En el país de la burundanga y el vacilón, donde el humor otorga legitimidad casi automática a la práctica literaria, escribir según la cita que se acaba de leer, es instalarse en el exilio como estrategia de supervivencia. ${ }^{10}$ La máquina

10 La singular fuerza de donde lleva a intelectuales puertorriqueños como Mara Negrón a decir: "No había sucedido esto en nuestro pensamiento literario ni político (hay una literatura no puertorriqueñista o trabajos para desmontar el nacionalismo) pero, quiero decir, alguien que quisiera con tanta contundencia

Revista Iberoamericana, Vol. LXXVIII, Núm. 241, Octubre-Diciembre 2012, 873-892
ISSN 0034-9631 (Impreso) 
de escritura tritura al espacio, lo devora y lo regurgita completo solo cubierto con la baba reluciente del lenguaje, que por más que brille es solo eso, baba. Hace falta un cínico para caminar el donde con estas herramientas, aceptar "la deriva como aprendizaje". ${ }^{11}$

Los países invisibles comienza así: “El mundo ya no es el mismo porque ya no es diferente.” La homologación que el Capital extiende por el mundo como único destino posible, donde una toalla es la misma en Aibonito, Puerto Rico; y en Ankara, Turquía mientras la basura se acumula en Calcuta y en Río de Janeiro, es la forma visible del exterminio, del odio con el que Occidente iguala y destruye. Sin embargo, la negación de Occidente sigue siendo occidental (Negrón 308) Lalo se inserta en una larga tradición de repudiadores (Nietzsche, Sade, Cioran, Onetti) que han forjado el espacio espeso, que han enarbolado la marca del desasosiego como único estandarte.

Los países invisibles está dividido en tres secciones: "El viaje”, "La carretera número 3” y "El experimento”; las tres son estadios de un ambicioso proyecto teórico y se complementan como kundalini de figuras entrelazadas. Lalo, en varias ocasiones, ha llamado a este texto novela (como lo hizo con donde) y la lectura que aquí apuntalo concuerda con esta idea. donde y Los países invisibles son exploraciones de un personaje, ${ }^{12}$ en el escenario del presente con el argumento del efecto del lugar y del tránsito en los personajes. Los países invisibles es un ensayo, que es desde Montaigne hasta Borges, un lugar donde el sujeto moderno desarrolla la singularidad de una postura frente el meollo de su existencia y su entorno. Para el filósofo Theodor W. Adorno el ensayo es un primo molesto de la filosofía que "explicita la plena consecuencia de la crítica al sistema” (19). Este tipo de texto hace aparecer una frontera entre el sujeto y el objeto; al tender sus inquietudes hacia un espacio no clasificable por el conocimiento científico termina por no adentrarse en la pura subjetividad sin abandonar la práctica subjetiva. "El ensayo carga sin apología con la objeción de que es imposible saber fuera de toda duda qué es lo que debe imaginarse bajo los conceptos” (Adorno 22). El ensayo-novela de Lalo entra de lleno en esta ambigüedad del género, o, mejor, en esta generosidad que brinda el ensayo. La textura de Los países acoge esta característica del ensayo, la de ser un habitante de los márgenes de la filosofía mientras se es un lugar de libertad desde donde es posible impugnar la invisibilidad.

La primera sección recoge un viaje por algunas ciudades europeas, lo que le sirve al narrador para especular que la globalización es algo así como una mancha que lo iguala todo y que, consecuentemente, invisibiliza. Las ciudades cada vez se parecen más porque el mundo asiste a un ejercicio sistemático de homologación. Para Lalo la homologación

habitar en el desarraigo, hacer de eso una poética que no es otra cosa que hacerse un lugar, producir una marca que permanece a través de la escritura y de la foto, yo no lo he visto, leído aquí” (305).

11 Tomo esta frase del título de un capítulo del libro de Ricardo Forster: W. Benjamin, Th. W. Adorno: El ensayo como filosofia.

12 Que en donde ya lo encontrábamos en frases como “Escribir es la aventura del viaje inmóvil”.

Revista Iberoamericana, Vol. LXXVIII, Núm. 241, Octubre-Diciembre 2012, 873-892
ISSN 0034-9631 (Impreso) 
que produce la globalización tiene la consecuencia ético-estética de la invisibilización; el acto real de moverse es inútil porque Londres, Madrid, Venecia y San Juan han sido vaciadas de su singularidad por el impulso globalizador hasta convertirlas en tarjetas postales. Lo invisible (o el efecto de invisibilización) es el lugar que el sistema mundo (o el Imperio, si se prefiere la terminología de Antonio Negri) le asigna a lo que no se deja liquidar, erradicar de la pantalla de lo representable. La literatura ocurre precisamente ahí, es el eco de lo erradicable, como los mundos salvajes de Roberto Bolaño, lo literario ocurre un poquito más allá de los márgenes de lo visible: "La invisibilidad es una de las formas que adquiere la tragedia” (Los países 31). Por supuesto, es singular que este paseo se realice por ciudades europeas, un sujeto se interpela con ese itinerario, cierta historia de la subjetivación se va construyendo con la escritura que se forma en el camino por las ciudades. La escritura occidental posiblemente esté saturada de la paradoja urbanidad/ borradura. La escritura de Lalo enfatiza su presencia en la barra que separa el binomio arriba inscrito, mientras insta al lector a considerar la genealogía del sujeto occidental.

La segunda sección explora otra forma de invisibilidad quizá más íntima, más local. Un paseo por una de las carreteras principales de Puerto Rico se convierte en una parsimoniosa excursión a través del desastre. La carretera \#3 atraviesa toda la costa noreste de la Isla y es una vía rápida para llegar a San Juan. En los últimos 40 años las tierras que conectan con La carretera \#3 han sido brutalmente depredadas por proyectos de vivienda y por centros comerciales. La acelerada industrialización que sufrió la Isla (piedra de toque de la administración de Luis Muñoz Marín, primer gobernador electo por puertorriqueños en 1952), convirtió a Puerto Rico en una víctima gozosa de la tormenta del progreso. Lo trágico para Lalo es que el desastre no se vea, que sea invisible. La primera víctima de la globalización es la vista, en el presente la ceguera es la nueva hegemonía, pero no es la ceguera de Tiresias. La tiranía de la prosperidad anestesia la conciencia. “El mundo avanza hacia la exclusión del acto de mirar” (Los países 20).

Para Lalo el mundo avanza hacia la proliferación de países invisibles, en los que cada vez será más difícil ser alguien sin de antemano parecerse a otro. El efecto homologante de la globalización, en una colonia insignificante como Puerto Rico, provee el apoyo epistemológico para hacer desaparecer la diferencia. Ese es el futuro porque ese es el presente. Sin embargo, se engañan los que creen que Lalo es un escritor lúgubre o fatalista, no, es un radical de la celebración ${ }^{13}$ que anuncia que hay que estar atentos a los gestos invisibilizadores que el Otro lejano nos lanza como trampas para la conciencia, trampas que limitan la vida: "La invisibilidad atañe a la borradura de las diferencias

${ }^{13}$ Aquí hay que recordar a Deleuze nuevamente: “If you don’t admire something, if you don’t love it, you have no reason to write a word about it. Nietzsche and Spinoza are philosophers whose critical and destructive powers are without equal, but this power always spring from affirmation, from joy, from a cult of affirmation and joy, from the exigency of life against those who would mutilate and mortify life. For me, that is philosophy itself" (144).

Revista Iberoamericana, Vol. LXXVIII, Núm. 241, Octubre-Diciembre 2012, 873-892
ISSN 0034-9631 (Impreso) 
operadas por el proceso de acumulación global del capital” (Duchesne, "La verdadera historia” 1291). Lalo ofrece pocos consuelos y a veces suena como un predicador, pero cierto Nietzsche también suena así: "Esta sociedad [Puerto Rico] no está capacitada para ver lo que le ha ocurrido” (Lalo, Los países 159).

El esquema que anuncia la celebración Lalo lo formula en Los países invisibles siguiendo un modelo de la antigüedad griega. El cristianismo, en los últimos dos textos de Lalo, se construye como una especie de ataponamiento originario, una suerte de trauma extraordinariamente devastador que funda para Occidente una violencia atávica, un repudio visceral y emblemático a todo lo humano y “natural”. Los países invisibles es una terapéutica del donde, ambos se enlazan por una misma voluntad descriptiva y filosófica, pero Los países invisibles lanza al ruedo al cínico, al “perro”, un pensadorcaminante aún no contaminado por el cristianismo.

Los cínicos fueron un movimiento o una escuela ${ }^{14}$ filosófica, de raíz socrática, de la Grecia antigua que proponían como vida ejemplar la de aquél que renuncia a los beneficios y placeres que la sociedad provee. El mundo, para los cínicos, pertenece a todos y el sufrimiento emana de la mala conciencia de otorgarle valor a lo que no lo tiene y de las costumbres que apoyan estas nociones. Los cínicos fomentan una "vida mínima” (Dudley ix), con las menos posesiones posibles, que es lo que ellos llaman una vida "natural”. A simple vista es evidente que el cinismo no tiene nada que ver con el capitalismo; si la acumulación y el gasto es una de las premisas del capitalismo, entonces el estilo de vida cínico no tiene mucho que ofrecer a este sistema. Esta tensión entre el Capital y la práctica individual es importante conservarla al leer la tercera sección de Los países invisibles, “El experimento”. Los cínicos se insertan en el experimento de Lalo por la deliberada marginalidad que informa sus principios.

Hay que matizar lo que se entiende por cinismo en Los países invisibles. El manejo peyorativo que cultural y popularmente se le otorga al cínico, una especie de bufón que no le importa nada de la vida, hay que abandonarlo a la hora de leer este texto. No nos bastan las definiciones como la del Diccionario Abreviado del Español Actual de Manuel Seco: “[...] que miente con descaro, que actúa con desvergüenza contra la moral comúnmente admitida”, ${ }^{15}$ porque Lalo está aludiendo a la práctica cínica clásica de la filosofía como vida a la intemperie. La mente crítica y cínica entiende que la separación entre filosofía y literatura es muy fina, casi inexistente. Una membrana muy delgada separa la actitud filosófica de la actitud literaria que señala la definición del escritor que favorece Lalo. En Los países invisibles lo cínico es la práctica de la desesperanza, porque el escritor es quien sabe que la desesperación es el único puerto que le queda

${ }^{14}$ Los estudiosos de esta materia no se ponen de acuerdo. Al cinismo, como no tiene un corpus dogmático, algunos prefieren llamarlo movimiento o secta socrática. Véase las introducciones de Bracht Branham y Donald Dudley citadas en la bibliografía.

15 Aunque la última parte recoge la actitud cuestionadora del cínico.

Revista Iberoamericana, Vol. LXXVIII, Núm. 241, Octubre-Diciembre 2012, 873-892
ISSN 0034-9631 (Impreso) 
al que todavía opta por estar vivo. Para Michel Onfray el cinismo es un "elogio de la fuga” (Onfray 63), una huida positiva cuando las coordenadas que cifran la realidad han ocultado la Vida en un estruendo insoportable... pero es un estruendo que no toca la interioridad del temperamento cínico: "El cínico apela a la duda sistemática e instala el escepticismo en el corazón mismo de los lugares comunes: promueve una lógica emancipadora” (Onfray 119). Cínico significa literalmente, “como un perro”, quizá porque de los cínicos se esperaba que se comportaran como un perro, que orinaran en cualquier sitio, que se rascaran las pulgas en cualquier reunión. A los cínicos se les vinculó originalmente a Sócrates. Un proto cínico, Antístenes, aparece en los diálogos de Platón conversando y discutiendo con Sócrates. Pero es con Diógenes de Sínope con quien tenemos la personalidad más emblemática de los cínicos. Existe muy poco material histórico sobre Diógenes - o sobre los cínicos en general-pero se sabe que vivió en el siglo IV antes de Cristo, que argumentaba que la filosofía es un hacer corporal del día a día y que rehuía de las dogmatizaciones de las escuelas y los códigos. A través de fuentes secundarias y de las anécdotas que recoge Diógenes Laercio en su Vidas y opiniones de filósofos famosos escrita en algún momento del siglo III de nuestra era, se logra reconstruir parte de su vida y de sus ideas que Lalo se apropia y lleva al texto como propuesta ante la invisibilidad, como resistencia, no para hacerse visible sino para quitarle valor a esa forma de visibilidad que favorece el poder. Platón llamó a Diógenes “un Sócrates enloquecido” porque llevó la doctrina socrática, vivir para el pensamiento, a su fundamento mínimo, al extremo de mendigar y vagabundear.

Haciendo suyas algunas de las categorías de Bajtin, R. Bracht Branham dice sobre Diógenes: "Diogenes is a dialogical figure, a hero of improvisation not of tradition... In choosing to reject the socially produced categories by which his contemporaries organized their lives, Diogenes made himself an object of experimentation and representation” (86). El cinismo es una actitud política para épocas adversas. La vida es una performance de la inteligencia: pensar es pensar con el cuerpo. Dice Lalo sobre donde y Los países en entrevista realizada por j. a. bonilla: "Estos libros contienen el itinerario del descubrimiento de un cuerpo reconstruido que ambiciona ser operante” (bonilla 25). El cínico es el paradigma que Lalo extrae de la historia para oponerlo a la pasividad inoperante a la que nos condena el presente, esa sutil (y tenebrosa) forma de la apatía que ha transformado la libertad en la “opción” de escoger entre helado Breyer o Haagen-Dazs en el supermercado de la esquina: "Diógenes detesta más que nada a los hombres que contribuyen con ardor y determinación a su propia alienación y se abandonan al azar y la suerte con la mayor de las pasividades. Los cínicos aborrecen la indolencia. La acción supone un compromiso y un conflicto con lo real, un combate singular con la resistencia del mundo" (Onfray 85-86).

El experimento en la última sección de Los países invisibles es un experimento cínico. Ante el panorama del donde y la carretera \#3, Lalo apuesta por una sospecha

\footnotetext{
Revista Iberoamericana, Vol. LXXVIII, Núm. 241, Octubre-Diciembre 2012, 873-892 ISSN 0034-9631 (Impreso) IISN 2154-4794 (Electrónico)
} 
lúdica radical. La práctica cínica arruina el proyecto capitalista que solo beneficia a los reyes del mercado, le da coherencia a una vida para el pensamiento, la amistad y la felicidad y echa a andar la idea de un proyecto de un exilio permanente como forma del estar en el mundo: “Olvidamos que la filosofía antes de que el cristianismo la volviera una escolástica, era una forma de comer, de caminar, de actuar o de sentarse en el suelo” (bonilla 2008):

Thus the ideology of Cynicism originates as the set of rhetorical strategies Diogenes invented to make persuasive sense of such "minimal living", so at odds not only with the traditional aristocratic notions of a desirable life, but with the existing models of the philosophic life as well. The practice of "Cynicism" -from "doglike"- came to mean living as circumstances had taught Diogenes to live: in exile both literally and metaphorically. (Branham 90)

No recuerdo ahora dónde lo leí, pero sirve para entender a Lalo: la verdadera revolución no consiste en un salto hacia adelante, sino en VER clara y convincentemente el lugar en el que podemos decir “hasta aquí debemos llegar”. Las lógicas del escepticismo y el ascetismo ${ }^{16}$ que se infieren de "El experimento” son la propuesta del cínico contra el mundo-único hacia el que aparentemente nos dirigimos. Hay que sospechar de cierto (¿falso?) materialismo que agota las posibilidades de acción de los seres humanos en la puerta de Wal-Mart o en el menú de restaurantes sofisticados. Dice Pierre Hadot sobre el cínico: "Su cuidado de sí mismo es, inseperablemente, un cuidado de los demás” (125).

Los países invisibles forma junto con donde un manual de resistencias que no se había visto antes en la literatura puertorriqueña. Un intento por romper las torpezas coloniales desde la colonia misma, glosando una diferencia a partir de una grieta de la pared que invisibiliza. Retoma la tesis “insularista”, la desviste de sus ropajes clasistas y le inyecta una dosis de cinismo que desterritorializa la forma de hegemonía que crea el canon:

Estos tres libros (Los pies de San Juan, donde y Los países invisibles) van abriendo el campo de acción de una mirada a través de actos de pensamientos. Se pasa de la consideración del espacio de una ciudad "natal", que adquiere esta cualidad a través de la intención de volverla una ciudad literaria, la invención de un concepto -el "donde"que vendría a resignificar y alterar las usuales consideraciones de la identidad a, finalmente, una discusión sobre el continuo visibilidad/invisibilidad en un marco mucho más amplio. (bonilla 24; énfasis mío)

${ }_{16}$ Aquí también hay que desechar la terminología cristiana que acerca al asceta al casto, a las prácticas de la contención. Pienso más en la definición griega de la palabra, askēsis, entrenamiento, disciplina.

Revista Iberoamericana, Vol. LXXVIII, Núm. 241, Octubre-Diciembre 2012, 873-892
ISSN 0034-9631 (Impreso) 
Los países invisibles y donde intentan hacer volátil el territorio de la identidad, mostrar el fétido terreno pantanoso que realmente ésta es para la práctica de la escritura y el pensamiento. Todas las toneladas de tinta que se han derramado por ella solo han conseguido ahogar al artista, mostrarle la camisa de fuerza con la que se supone que escriba, pinte, esculpa, componga. Literaturas más complejas que la puertorriqueña, como la norteamericana o la del cono sur, saben hablar de lo que son sin que se escuche en ellas el rumor rancio de la historia o el tedio del tipo agazapado en la esquina. Son literaturas con personajes que se forjan en el texto, nunca fuera de él. La literatura la escribe quien no tiene nada que perder y en Puerto Rico se escribe como protegiéndose contra una pérdida de algo simbólico, contra la amenaza imaginaria de la desaparición, como diciendo: 'ey aquí estoy, mírenme’. Palés, Kafka, Onetti, Pessoa, escriben desde el hueco, acaso convencidos de que desaparecer no importa, que ese es quizá el único lugar del que se puede escribir.

"Perdura una sombra, una grieta, en los más sólidos monumentos y por medio de ellas, se puede, acaso tenuemente, hacer vivir un cuerpo que escribe. Un cuerpo arcaico, preplatónico y precristiano, que a mi modo de ver puede resultar sorprendentemente una de las grandes aventuras de nuestro tiempo" (bonilla 25). Sin embargo, este ejercicio de Lalo, que me arriesgo a llamar primitivista tomando en cuenta tanto sus consideraciones filosóficas como las plásticas, podría resultar uno fútil si se examina con los ojos del ángel de la historia, ¿̇no es la acumulación de escombros un proceso irreversible? ¿La saturación a la que el presente nos expone no vuelven insignificantes estas prácticas minimalistas? Es sobre las marcas de irreversibilidad e insignificancia contra las que se vierte el acto de Lalo, su apuesta por la resistencia. Este "cuerpo que escribe”, precristiano, puede leerse con las claves de las políticas de la afectividad del filósofo Herman Herlinghaus. Para este, Occidente lleva a cabo una feroz guerra contra los afectos que lanza a una inmensa porción de la sociedad a las franjas lejanas de la vida, pero desde esos márgenes emerge un gesto radical marcado por la diferencia y el placer: "We are dealing with existence on a social and ethical edge that is both threatened and reaffirmed [...] Life comes to be consecrated in the limbo where social subsistence is threatened with collapse” (Herlinghaus 120). Adapto aquí estas nociones críticas a la literatura de un escritor caribeño; Herlinghaus las utiliza para analizar películas del "sur profundo" latinoamericano y las líricas de los narco corridos. El poeta-ensayista se adentra por la ciudad con la lucidez de la derrota, con la victoria implícita de quien ya no tiene nada que perder, pero es en ese margen donde se descubre al cuerpo pensante, al cuerpo caminante, la escritura aparece en el encuentro entre el cuerpo y la ciudad. A este gesto yo no llegaría a llamarlo una "ética del fracaso" (Duchesne, "Desde donde”) sino una política del desarraigo, un empoderamiento de una "marginalidad afectiva" (Herlinghaus) que lanza a la urbe lo único que tiene, su cuerpo. Por eso a la voz del ensayista le incomoda utilizar la palabra fracaso y prefiere hablar de póstumo o quedado:

\footnotetext{
Revista Iberoamericana, Vol. LXXVIII, Núm. 241, Octubre-Diciembre 2012, 873-892 ISSN 0034-9631 (Impreso)

ISSN 2154-4794 (Electrónico)
} 
"La escritura es un acto de supervivencia aunque no se pueda nombrar la catástrofe" (Lalo, Los países 128). El póstumo-flâneur-cínico así podría configurarse la criatura que los textos de Lalo lanzan al escenario literario, alguien que se entrelaza con la máquina de afectividades para evadir la domesticación del Otro lejano.

Eduardo Lalo es a nuestra época lo que Manuel Ramos Otero fue a la suya: un profanador:

\begin{abstract}
Nosotros los escritores, solo tenemos palabras para expresar la misma crueldad que nos domina y estamos sometidos a la tarea exhaustiva de buscar la palabra que expresará, de alguna forma, con precisión y astucia, la emoción experimentada en nuestros oídos mentales donde un bisturí invisible, o la idea platónica de dicho bisturí, escarbó la sensación de miedo hasta dejarnos como un hueso sin tuétano que luego nos permita recordar nuestro destino, más allá de la soledad necesaria para que los lectores anticipen la muerte. (Ramos Otero 29)
\end{abstract}

La escritura de Eduardo Lalo hay que leerla en ese registro. La literatura del hueso sin tuétano, que enlaza pensamiento, dolor, peregrinaje y cuaderno. Como sugiere el epígrafe de Ramos Otero, la literatura que promete el texto de Lalo, anuncia que es preciso sacrificar cierta idea de la literatura puertorriqueña para que de su cadáver ensangrentado nazca una estética sin compromisos.

\title{
OBRAS CITADAS
}

Adorno, Theodor W. “El ensayo como forma”. Notas de literatura. Barcelona: Ariel, 1962. 11-36.

Amar Sánchez, Ana María. “Entrevista a Eduardo Lalo”. Katatay 6 (2008): 38-41.

Benjamin, Walter. The Writer of Modern Life. Essays on Charles Baudelaire. Michael W. Jennings, ed. Howard Eiland, Edmund Jephcott, Rodney Livingston y Harry Zohn, trads. Cambridge: The Belknap Press, 2006.

“The Storyteller”. Illuminations. Hannah Arendt, ed. Harry Zohn, trad. Nueva York: Schocken Books, 1985. 83-109.

“A Berlin Chronicle”. Reflections. Peter Demetz, ed. Edmund Jephcott, trad. Nueva York: Schocken Books, 1986. 3-60.

bonilla, j. a. "Profeta del ocaso inmóvil: Entrevista a Eduardo Lalo con motivo de la publicación de Los países invisibles”. Diálogo (marzo-abril 2008): 24-25.

Branham, R. Bracht y Marie-Odile Goulet-Cazé. The Cynics. The Cynic Movement in Antiquity and Its Legacy. Berkeley: U of California P, 1996. 1-27; 81-104.

Buck-Morss, Susan. Dialéctica de la mirada. Walter Benjamin y el proyecto de los pasajes. Nora Rabotnikof, trad. Madrid: Visor, 1995.

\footnotetext{
Revista Iberoamericana, Vol. LXXVIII, Núm. 241, Octubre-Diciembre 2012, 873-892 ISSN 0034-9631 (Impreso) ISSN 2154-4794 (Electrónico)
} 
Costa, Marithelma. "Manuel Ramos Otero Entrevista”. Hispamérica XX/59 (agosto 1991): 59-67.

De la Nuez, Iván. "Berlín: un paseo en Trabant por el poscomunismo”. Berlin tendenzen. Barcelona: Institut de Cultura de l’Adjuntament de Barcelona, 2006. 22-28.

Demetz, Peter. "Introduction”. Reflections. Walter Benjamin. Nueva York : Schocken, 1986. vi-xliii.

Deleuze, Gilles. Desert Islands and Other Texts. David Lapoujade, ed. Michael Taormina, trad. Los Angeles: Semiotext(e), 2004.

y Félix Guattari. Kafka por una literatura menor. Jorge Aguilar Mora, trad. México: Era, 2001.

Duchesne, Juan. "Fatiga de indentidad”. Fugas incomunistas. San Juan: Vértigo, 2005. 17-36.

"Desde donde alguien para leer a Eduardo Lalo" Katatay 6 (2008): 7-16.

"La verdadera historia del hombre invisible” (Reseña de Los países invisibles). Revista Iberoamericana 229 (octubre-noviembre 2009): 1288-1292.

Dudley, Donald R. History of Cynicism: From Diogenes to the $6^{\text {th }}$ Century A.D. Londres: Methuen, 1937.

Hadot, Pierre. "Las escuelas helenísticas”. ¿Quées la filosofia antigua? Eliane Cazenave Tapie Isoard, trad. México: Fondo de Cultura Económica, 1998. 105-162.

Herlinghaus, Hermann. Violence without Guilt: Ethical Narratives from the Global South. Nueva York: Palgrave Macmillan, 2009.

Lalo, Eduardo. La isla silente. San Juan: Isla Negra, 2002. Los pies de San Juan. San Juan: Tal Cual, 2002. La inutilidad. San Juan: Callejón, 2004. donde. San Juan: Tal Cual, 2005. Los países invisibles. San Juan: Tal Cual, 2008.

Negrón, Mara. "Proivida la entrada”. De la animalidad no hay salida... Ensayos sobre animalidad, cuerpo y ciudad. San Juan: La Editorial Universidad de Puerto Rico, 2009. 303-308

Onfray, Michel. Cinismos: Retrato de los filósofos llamados perros. Alcira Bixio, trad. Buenos Aires: Paidós, 2005.

Quintero Herencia, Juan Carlos. "La escucha del desalojo: Paseos y errancias en Cada vez de despides mejor de José Liboy y donde de Eduardo Lalo”. Katatay 6 (2008): $17-24$

Ramos, Julio. "Introducción”. Amor y anarquía los escritos de Luisa Capetillo. Río Piedras: Huracán, 1992.

Ramos Otero, Manuel. "La heredera”. Página en blanco y staccato. Madrid: Editorial Playor, 1988.

\footnotetext{
Revista Iberoamericana, Vol. LXXVIII, Núm. 241, Octubre-Diciembre 2012, 873-892 ISSN 0034-9631 (Impreso) 


\section{Marginalia}

Mi madre murió de cáncer el 28 de agosto de 2004. Sin ser una gran lectora, de alguna manera entendía que el mundo, el caminante y el cariño eran una misma cosa. Ella me instó a leer y a viajar. En el 1983 me regaló mi primer libro importante Aventuras de Arthur Gordon Pym de Poe, yo tenía 10 años. Lo tengo frente a mí ahora mismo. Si un texto no se comunica íntimamente con tus intensidades, si no te abre un surco interior que traza un puente con los demás, entonces mejor dejarlo dormir su sueño de polvo y olvido. Este ensayo es para ti.

ISSN 0034-9631 (Impreso) 